\title{
THE BEHAVIOR OF HEGY TESTS FOR QUARTERLY TIME SERIES WITH SEASONAL MEAN SHIFTS
}

Artur C. B. da Silva Lopes o Instituto Superior de Economia e Gestão (ISEG-UTL) and Centro de Matemática Aplicada á Previsão e Decisão Económica (CEMAPRE), Lisboa, Portugal

Antonio Montañés o Universidad de Zaragoza, Zaragoza, Spain

o This paper studies the behavior of the HEGY statistics for quarterly data, for seasonal autoregressive unit roots, when the analyzed time series is deterministic seasonal stationary but exhibits a change in the seasonal pattern. We analyze also the HEGY test for the nonseasonal unit root. Our results show that when the break magnitudes are finite, the HEGY test statistics are not asymptotically biased toward the nonrejection of the seasonal and nonseasonal unit root hypotheses. However, the finite sample power properties may be substantially affected, the behavior of the tests depending on the type of the break.

Keywords HEGY tests; Seasonality; Structural breaks; Unit roots.

JEL Classification C22, C52 